machine by which he had done it, telling me that he had thought of it twenty years before. I could easily see by the colour of the ink and paper that it must have been done many years. $\mathrm{He}$ then told me, what was very certain, that he had neither stolen the thought from me, nor had I from him; and from that time till his death, Mr. Ellicott was one of my best friends."

The editor of my copy of Ferguson's works, "David Brew. ster, A.M., 1803," adds that James Ferguson was elected a Fellow of the Royal Society without paying the usual admission fees. This honour he shared with Sir Isaac Newton and Mr. Thomas Simson, the self-taught mathematician. Two Scottish philosophers-David Hume and James Ferguson-died in 1776 , both leaving autobiographies of singular beauty and pathos. Our own Huxley, who like James Ferguson was afflicted with "an ineradicable tendency to try to make things clear," has done the same in recent times. Two questions instantly present themselves: (I) On how many distinguished men has this honour been conferred by the Royal Society since these times? and (2), Is there a "watchmaker" now in that learned body?

Kimbolton, September 24 .

\section{A Case of Inherited Instinct.}

I THINK the interesting cases mentioned by Captain Hutton on p. 4II will hardly bear the interpretation he puts upon them. In New Mexico three genera of Stenopelmatina are common, viz., Stenopelmatus, Centhophilus and Udeopsylla. These locusts are nocturnal, and live under logs or in holes in the ground during the day. It is natural, therefore, that they should be attracted by any dark place, such as a cave. The species of Centhophilus, like the crickets, are found in houses, which are well adapted to their tastes. There is no new instinct, or revival of a dormant one, exhibited in this choice. Similarly, in Colorado I have found the species of Centhophilus to live in mines, which are practically caves of recent origin.

The cave-seeking instinct, therefore, has been practically continuous, and if in New Zealand one genus (Pachyrhamma) lives in caves, while its ally (Gymnoplectron) is arboreal, it is probable that the former retains the instincts of their common ancestor, while the latter has lost them, so far as the arboreal habit is concerned.

T. D. A. Cockerell.

Mesilla Park, New Mexico, U.S.A., September I5.

\section{Maggots in Sheep's Horns.}

In a letter which appeared in your issue of September 29, Captain Traherne writes under the heading of "Hornfeeding Larvæ," of maggots of about half an inch in length and of a white colour, having been found in the horns of a newly killed sheep, which he had obtained in India, but where there were no perceptible signs of perforation. These were not the larvæ of a Lepidopterous insect, but of one of the Diptera, known as CEstrus ovis, a well-known parasite. The fly lays her eggs in the region of the anterior nares, and the larvæ penetrate the nasal passage, finding their way into the turbinal bones, and from thence into the frontal cavity to the base of the horns. Captain Traherne does not say how far up the horn he found them; they are not usually found beyond the base, but as a rule locate themselves at the back of the throat, where they feed on the mucous substance. They are not horn feeders. Estrus ovis is distributed pretty generally wherever sheep are to be found.

Mr. Austen, of the British Museum (Nat. Hist.), showed me some very fine specimens, both of the fly and the larvæ. W. H. McCorquodale.

\section{"Luminous Clouds," or Aurora?}

SURELY the "luminous clouds" reported from Cornwall on September Io, in your issue of September 29, were auroral. It is a pity if no other record of altitude has been made, when one observation of such precision is available. I myself have a fairly good record of the upper edge of the bright arch, low down in the N.W. on the previous evening at I I p.m., as seen from Croydon. If others have a record of this, a comparison might be of value.

It may be worth noting the very probable recurrence of auroræ on the evenings beginning with the 6th inst., when the solar revolution produces the conditions of the last magnetic outbreak, so far as the aspect of the sun is concerned. I have been much struck by this recurrence in working up a series of unpublished auroral observations from York, dating back to I832.
I 2 Wool Exchange, E. C.
J. Edmund Clark.

September 30.

\section{A Hairless Rat.}

I SHOULD like to draw the attention of your readers to a peculiar case which may be worth notice.

About ten days ago a man employed at the Ordnance Store Department, Stonehouse, brought me what he termed a "real curio." It was a rat, adult though not very old, without any hair on its body. It was caught in an ordinary trap at the Victualling Yard, and it is still alive, active and, to all appearance, healthy.

In appearance the rat is of a brownish colour, and with the exception of its whiskers, which are normal, and an occasional long woolly hair on the body, it is quite hairless. When at rest the skin is thrown into numerous small folds or corrugations, and its colour is heightened by the dirt which collects in these folds. In active movement the folds disappear. The tail, except an inch at the base, is normal in appearance, though devoid of hair. The ears appear rather larger than usual, and the eyes are somewhat prominent.

On communicating with the Superintendent of the Zoological Society's Gardens, I was referred to a paper by J. S. Gaskoin, in the Proceedings of the Zoological Society for 1856 . A precisely similar case is there described, concerning four mice captured at Taplow in 1854 . One of these gave birth to five young, shortiy after capture, and these resembled the parent in every respect. There is no plate in the copy of the Proceedings that I have referred to, and the only difference in the description of the mice which does not fit my specimen is the colour of the ears, which are light coloured. T. V. HoDGSON.

Municipal Museum, Plymouth, September 29.

\section{THE DYNAMICAL THEORY OF REFRAC- TION, DISPERSION AND ANOMALOUS DISPERSION. ${ }^{1}$}

THE dynamical theory of dispersion, as originally given by Sellmeier, ${ }^{2}$ consisted in finding the velocity of light as affected by vibratory molecules embedded in ether, such as those which had been suggested by Stokes ${ }^{3}$ to account for the dark lines of the solar spectrum. Sellmeier's mathematical work was founded on the simplest ideal of a molecular vibrator, which may be taken as a single material particle connected by a massless spring or springs with a rigid lining of a small vesicle in ether. $\mathrm{He}$ investigated the propagation of distortional waves, and found the following expression (which I give with slightly altered notation) for the square of the refractive index of light passing through ether studded with a very large number of vibratory molecules in every volume equal to the cube of the wavelength :-

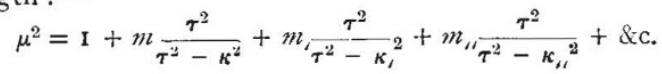

where $\tau$ denotes the period of the light ; $\kappa_{,} \kappa_{i}, \kappa_{i n}$ \&c., the vibratory periods of the embedded molecules on the supposition of their sheaths held fixed; and $m, m_{l}, m_{\mu}, \& \mathrm{c}$, their masses. He showed that this formula agreed with all that was known in 1872 regarding ordinary dispersion, and that it contained what we cannot doubt is substantially the true dynamical explanation of anomalous dispersions, which had been discovered by Fox-Talbot ${ }^{*}$ for the extraordinary ray in crystals of a chromium salt, by Leroux ${ }^{5}$ for iodine vapour, and by Christiansen ${ }^{6}$ for liquid solution

1 Abstract of part of the substance of a communication by Lord Kelvin, G.C.V.O., to Section A of British Association at Bristol, on September 9. 2 Sellmeier, Pogg. Ann., vol. 145, 1872, pp. 399, 520; vol. 147, 1872, pp. $386,525$.

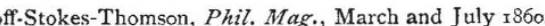

4 Fox-Talbot, Proc. Roy. Soc. Edin., I870-7I.

5 Leroux, Comptes rendus, 55, 1862, pp. 126-128.

6 Christiansen, Ann. Phys. Chent., r4I, I870, pp. 479, 480 ; Phil. Mag. 4 I, 1871, p. 244; Annales de Chimie, 25, 1872, pp. 213, 214.

NO. I 5 IO, VOL. 58 ] 